\title{
UNDERSTANDING OF SMART CITIES, DIGITAL CITIES AND INTELLIGENT CITIES: SIMILARITIES AND DIFFERENCES
}

\author{
D. Çinar Umdu ${ }^{1, *}$, E. Alakavuk ${ }^{2}$ \\ ${ }^{1}$ Yasar University, Graduate School PhD in Architecture, 35100 Bornova İzmir, TURKEY - duygu.cinar.88@gmail.com \\ ${ }^{2}$ Yasar University, Faculty of Architecture, Department of Architecture, 35100 Bornova İzmir, TURKEY - \\ ebru.alakavuk@yasar.edu.tr
}

KEY WORDS: Smart City, Digital City, Intelligent City, Similarities, Differences

\begin{abstract}
:
The modern world is fast in many ways and a place where technological innovations can be adapted immediately. This speed and technological progress can be seen as a kind of development. It has positive as well as negative aspects. Economic and social problems, population growth, consumption of resources, high energy use, environmental pollution and climate change are negative phenomena brought by the modern world. Cities can also be seen as units that work on different strategies and models due to fast living, environmental, social and economic problems. Especially developing urban technology, the increase in the population rate in the cities and environmental problems have led to the development and discussion of many terms and concepts in the architecture and design literature in the urbanization process. The word and concept accumulation they possess is too much to ignore. The concepts of smart city, digital city and intelligent city are the concepts put forward to solve the problems caused by the urban developing world. These three concepts are based on the use of urban technology and they are either confused with each other or their boundaries are not determined too much. In this study, while determining the boundaries of these concepts, which have a lot in common with each other, similarities and differences between the concepts were revealed and suggestions were made regarding the definitions of the concepts.
\end{abstract}

\section{INTRODUCTION}

The modern world is a fast and technologically open space. It is an integrated system open to both physical, virtual, and social developments. In addition, the information age, innovations and entrepreneurship have influenced and developed many things in the urban dimension as well as in every field (Velibeyoğlu, 2016).

Technology, climate change and fast life brought many terms to our lives. While some point to the same concepts, others have changed their boundaries and definitions. Today, many disciplines have met several terms that have not yet been defined, or even whose boundaries are completely drawn.

One of these disciplines are design and architecture. Urbanization is one of the most important issues of architectural discipline, and according to the European Commission, more than $70 \%$ of the world's population will live in cities (DGEnergy, 2019) by 2050. Even now, about $75 \%$ of the European population lives in cities (Kotzeva, Brandmüller, 2016).

This data indicates that energy consumption, the virtual network and various social and economic formations are concentrated in cities to a large extent. Cities are the main drivers of the world economy and culture, also they open effective ways for growth, socialization, and employment (Ateş, Önder, 2019; DG-Energy, 2019).

The characteristics of the cities in the old world were shaped by the industrial development of the structural features of the buildings in that city (Mittchel, 2007). The features of the cities are shaped by the city technologies they hold. Now the performance of a city is not only related to its physical

\footnotetext{
* Corresponding author
}

structures, but also to its social, economic, environmental, and technological structures (Caragliu et al., 2011).

But it should not be forgotten that the urbanization process brings with it many environmental, economic, and social problems (Braun, 2005; Çelik, Güleç, 2014). To solve this problem, many definitions have been made on urban basis and various models have been developed and many of them are based on urban technology (Velibeyoğlu, 2016). But some of them were either confused or unable to form the main focal points.

In the context of the solution of the problems related to urbanization, smart city, digital city, data city, tele city, eco city, intelligent city, info city, sustainable city, global city and many more are defined in the literature.

In this study, the conceptual features, similarities and differences of the terms smart city, intelligent city and digital city, which are defined in the technological and environmental development process of urbanization, are determined and their limits are defined. In addition, suggestions about the use of these terms are presented.

\section{METHODOLOGY}

In the study, a literature research was conducted on the concepts of smart city, digital city, and intelligent city. Several information, definition and terms about these concepts were collected. In line with this information, the basic features, characteristics, contents, and criteria of the concepts were examined.

In addition, these 3 concepts were searched in the search engines (Google, Bing and Yandex), which are the simplest 
method for non-disciplinary people to use them, to find out whether the definitions of concepts are also reached by nondisciplinary people and the results were compared.

Regarding the conceptual thoughts they want to reveal, similarities and differences of the terms and obstacles about the concepts have been put forward and a suggestion has been made on how these concepts should be handled in today's world.

\section{SMART CITY}

One of the concepts presented for the solution of the urban problems of the modern world is the smart city, which contains many definitions and models. It was handled in the 90 s for the first time, and its popularity became an increasing concept in the 2000s (Ateş, Önder, 2019; Dameri, 2013).

It is one of the solutions that correspond to the rapid urbanization challenges (Estevez et al., 2016) which is complex (Çelik, Güleç, 2014) and has more than one element (Dameri, 2013).

Many authorities, sectors and parties around the world have done many studies on this concept and economic programs and calls have been developed for these studies (Dameri, 2013; Engelbert et al., 2019; Batagan, 2011).

On the European Commission's policy-related website, it has defined the term: "A smart city is a place where traditional networks and services are made more efficient with the use of digital and telecommunication technologies for the benefit of its inhabitants and business." (DG-Energy, 2019, https://ec.europa.eu/digital-single-market/en/smart-cities).

At the same time, cities are the main drivers of the EU economy, opening up effective ways for growth and employment. There are several EU policies, proposals and initiatives that promote more attractive and competitive urban areas, a healthier and more sustainable place to live, and also combat climate challenges (DG-Energy, n.d.). The European Union has opened a call on Horizon 2020 on smart cities and continues to work on smart cities (Шнепс-Шнеппе, 2016).

Furthermore, this concept is a city vision, where the rapidly developing technology is used to increase the quality of life in urban processes, where social and environmental sustainability exists, and information technologies are used in many ways (Ateş, Öner, 2019).

The concept of smart city will be defined in different ways throughout the developing technologies and the process of the modern world. Because the economic, social and environmental problems of each period will change. Many urban and rural builders, not only smart cities, need to revise their policies for development sustainability (Alkan, 2015).

Moreover, many different definitions were shared in the Smart Sustainable Cities-Reconnaissance Study in 2016 by Estevez and her team. These definitions are presented in Table 1 .

\begin{tabular}{|l|c|c|}
\hline Definition & Who & Date \\
\hline $\begin{array}{l}\text { utilizing "the opportunities } \\
\text { presented by Information and }\end{array}$ & & \\
$\begin{array}{l}\text { Communication Technology (ICT) } \\
\text { in promoting ... prosperity and } \\
\text { influence." }\end{array}$ & Odendaal & 2003 \\
\hline
\end{tabular}

\begin{tabular}{|c|c|c|}
\hline Definition & Who & Date \\
\hline $\begin{array}{l}\text { investing "in human and social } \\
\text { capital and traditional (transport) } \\
\text { and modern (ICT) communication } \\
\text { infrastructure to fuel sustainable } \\
\text { economic growth and a high quality } \\
\text { of life, with a wise management of } \\
\text { natural resources, through } \\
\text { participatory governance" }\end{array}$ & $\begin{array}{c}\text { Caragliu et } \\
\text { al. }\end{array}$ & 2011 \\
\hline $\begin{array}{l}\text { "a high capacity for learning and } \\
\text { innovation, which is built-in the } \\
\text { creativity of their population, their } \\
\text { institutions of knowledge creation, } \\
\text { and their digital infrastructure for } \\
\text { communication and knowledge } \\
\text { management" }\end{array}$ & $\begin{array}{l}\text { Allwinkle, } \\
\text { Cruickshank } \\
\text { / Tranos, } \\
\text { Gertner }\end{array}$ & $\begin{array}{l}2011 / \\
2012\end{array}$ \\
\hline $\begin{array}{l}\text { a city where "ICT is merged with } \\
\text { traditional infrastructures, } \\
\text { coordinated and integrated using } \\
\text { new digital technologies." } \\
\text { "a fusion of ideas about how } \\
\text { information and communications } \\
\text { technologies might improve the } \\
\text { functioning of cities, enhancing } \\
\text { their efficiency, improving their } \\
\text { competitiveness, and providing new } \\
\text { ways in which problems of poverty, } \\
\text { social deprivation, and poor } \\
\text { environment might be addressed" }\end{array}$ & Batty et al. & 2012 \\
\hline $\begin{array}{l}\text { "User-centred evolution of the } \\
\text { other city-concepts which seem to } \\
\text { be more technological deterministic } \\
\text { in nature." }\end{array}$ & $\begin{array}{c}\text { Schuuman et } \\
\text { al. }\end{array}$ & 2012 \\
\hline $\begin{array}{l}\text { "how investments in human and } \\
\text { social capital and modern ICT } \\
\text { infrastructure and e-services fuel } \\
\text { sustainable growth and quality of } \\
\text { life, enabled by a wise management } \\
\text { of natural resources and through } \\
\text { participative government" }\end{array}$ & $\begin{array}{l}\text { Schaffers et } \\
\text { al. }\end{array}$ & 2012 \\
\hline $\begin{array}{l}\text { "urban environment which, } \\
\text { supported by pervasive ICT } \\
\text { systems, is able to offer advanced } \\
\text { and innovative services to citizens } \\
\text { in order to improve the overall } \\
\text { quality of their life" }\end{array}$ & Piro et al. & 2014 \\
\hline $\begin{array}{l}\text { "a generic term to describe IT- } \\
\text { based innovative urban } \\
\text { ecosystems" }\end{array}$ & Gabrys & 2014 \\
\hline $\begin{array}{l}\text { "smart ability to deal with a city's } \\
\text { problems and provides citizens with } \\
\text { a better living environment through } \\
\text { intelligent accumulation and } \\
\text { analysis of different kinds of data } \\
\text { from the city's routine operation } \\
\text { based on advanced information } \\
\text { technologies" }\end{array}$ & Wenge et al. & 2014 \\
\hline
\end{tabular}

Table 1 . The definitions used by experts for the term smart city In the Smart Sustainable Cities-Reconnaissance Study (Estevez et al., 2016, p.10-11). 
In the report it is highlighted that the smart city is a structure which is environment, economy, business, human capital, education and social based existing systems are protected and supported by technology and simulations, e-management adopted (Estevez et al., 2016).

It is a formation where sustainability and digitalization coexist and 119 cities in the world define themselves as smart city. Some of these cities are also defined as both intelligent city and digital city. (Estevez et al., 2016).

In Cities in Motion Index (CIMI) 2018, 165 cities from 80 countries in the world are listed in many respects and 25 smartest world cities are determined. These cities are given in Table 2.

\begin{tabular}{|c|c|c|}
\hline Rank & Country & City \\
\hline 1 & USA & NewYork \\
\hline 2 & UK & London \\
\hline 3 & France (European-27) & Paris \\
\hline 4 & Japan & Tokyo \\
\hline 5 & Iceland & Reykjavik \\
\hline 6 & Singapore & Singapore \\
\hline 7 & South Korea & Seoul \\
\hline 8 & Canada & Toronto \\
\hline 9 & $\begin{array}{l}\text { Hong Kong Special } \\
\text { Administrative Region of the } \\
\text { People's Republic of China }\end{array}$ & Hong Kong \\
\hline 10 & Netherlands (European-27) & Amsterdam \\
\hline 11 & Germany (European-27) & Berlin \\
\hline 12 & Australia & Melbourne \\
\hline 13 & Denmark (European-27) & Copenhagen \\
\hline 14 & USA & Chicago \\
\hline 15 & Australia & Sydney \\
\hline 16 & Sweden (European-27) & Stockholm \\
\hline 17 & USA & Los Angeles \\
\hline 18 & New Zealand & Wellington \\
\hline 19 & Austria (European -27) & Vienna \\
\hline 20 & USA & Washington \\
\hline 21 & USA & Boston \\
\hline 22 & Finland (European-27) & Helsinki \\
\hline 23 & Norway (European-27) & Oslo \\
\hline 24 & Swiss & Zurich \\
\hline 25 & Spain (European-27) & Madrid \\
\hline
\end{tabular}

Table. 2 The smartest 25 city of the world (Berrone et al. 2019)

According to this ranking, New York has become the smartest city in the world. 9 dimensions addressed when ranking are: Human Capital, Governance, Environment, Social Cohension, Economy, Mobility and Transportation, International Outreach, Urban Planning, Technology (Berrone et al. 2019).

The fact that 9 European-27 Cities, London from the UK and Zurich from Swiss are on the list show that European Union Countries and other European states' initiatives regarding smartness have positive effects on this issue. Europe has 11 cities in total of of 25 . With 5 smart cities, USA follows the European Union.

It should also be underlined that smart city applications in the world are handled differently (Alkan, 2015). While Europe leaves the smart city formation to local authorities, countries such as China and USA shape smart cities for state structures (Engelbert et al., 2019).

This type of conceptual difference actually provides more opportunities to synchronize the geographical, climatic, social, economic and environmental structures and technological structures of the cities but increases the administrative burden of local authorities.

To make a definition in line with all this, smart city is a technological infrastructure in which the data related to urbanization is converted to BIG DATA thanks to IoT (internet of things), but it is not only sufficient but it is constructed in environmental, social and economic order. With the help of technology, it is an urban model in which existing is preserved and developed and sustainable development is based.

\section{DIGITAL CITY}

By the Internet being a part of urban technology and using information systems on a city basis, the world met with digital cities. The concept of digital city started to develop with the network developed for Copenhagen's citizens in the 80s (van Bastelaer, 1998).

Cities are economic, political, and cultural attractions. While developing technology develops virtual networks, digital cities create these integrations in virtual spaces. (Schuler, 2002).

Based on the fact that it is based on information exchange and communication and the digital cities created have a community network, it is inevitable to transfer the real features of the city to you.

This is an urban space of flows situation that occurs with the network society that Castel is talking about (Castells, 2004; Castells, 1999).

A city creates virtual spaces with the widespread de-ruralisation and digitalization, and these virtual spaces become places where finance and society take place (Schuler, 2002).

In this transformation period, the physical and geographical location changes with the developing virtual space and becomes a global city (Sassen, 1991). Digital city is a model that combines social, cultural, economic, and educational elements (van Bastelaer, 1998).

Although digital cities, which can be called virtual city or tele city, are not always a global city, every global city can be considered as a digital city. Because the information obtained after a while takes place not only in the databases of local authorities, but also in the systems of economic parties (Sassen, 1991; van de Besselaar et al. 1999).

Every city that uses information and learning technology is digitalized. While the world itself is digitizing, its cities are also digitizing (Ishida, Isbister, 2000). 
The fact that millions of people who have to stay at home and live in different cities with their COVID-19 pandemic spend their time with the opportunities offered by digitalized cities emphasizes the importance of the formation of digital cities. Although it is not a problem in this process to go to concerts, exhibitions or museums through the internet (Paull, 2020), to visit cities and to get information about them, these cities have also served people in different cities by gaining a global identity.

When the definitions related to this concept are analysed, unlike the smart city definitions, they meet with each other with more consistent definitions. Some of definitions in literature is shown in Table 3.

\begin{tabular}{|c|c|c|}
\hline Definition & Who & Date \\
\hline $\begin{array}{l}\text { an online network connected, IoT } \\
\text { related city equipped with } \\
\text { technological platforms for } \\
\text { information and communication } \\
\text { management. }\end{array}$ & Enelx & n.d. \\
\hline $\begin{array}{l}\text { a virtual network-based bridge for } \\
\text { information exchange between } \\
\text { city authorities and citizens within } \\
\text { the system }\end{array}$ & $\begin{array}{c}\text { van } \\
\text { Bastelaer }\end{array}$ & 1998 \\
\hline $\begin{array}{l}\text { the complex relationship between } \\
\text { urban and technology is the link } \\
\text { between urban society and } \\
\text { information and communication } \\
\text { technologies. }\end{array}$ & $\begin{array}{l}\text { van de } \\
\text { Besselaar et } \\
\quad \text { al. }\end{array}$ & 1999 \\
\hline $\begin{array}{l}\text { a city transformed digitally or } \\
\text { reorganized by technology and a } \\
\text { digital representation or reflection } \\
\text { of some aspects of a real or virtual } \\
\text { city. }\end{array}$ & Schuler & 2002 \\
\hline $\begin{array}{l}\text { by the creative integration of } \\
\text { telecommunications into urban } \\
\text { policy and planning practices and } \\
\text { strategies created to have a more } \\
\text { inclusive and sustainable urban } \\
\text { future. }\end{array}$ & Nunes & 2005 \\
\hline $\begin{array}{l}\text { it is a community that is } \\
\text { interconnected and uses various } \\
\text { information and communication } \\
\text { technologies. } \\
\text { it is a flexible, service-based } \\
\text { computing infrastructure that } \\
\text { adopts open industry standards. } \\
\text { Innovative online services } \\
\text { provided for the needs of } \\
\text { governments, other sectors, } \\
\text { employees and citizens. }\end{array}$ & $\begin{array}{l}\text { Yovanof, } \\
\text { Hazapis }\end{array}$ & 2009 \\
\hline $\begin{array}{l}\text { an infrastructure in which digital } \\
\text { technologies and urban elements } \\
\text { are integrated. }\end{array}$ & $\begin{array}{l}\text { Estevez et } \\
\text { al. }\end{array}$ & 2016 \\
\hline
\end{tabular}

Table 3. Definitions in literature about digital cities

However, some people define the term digital city as designing rhizome formations and creating organic forms in city silhouettes thanks to digital technologies, but this is a purely physical (Leach, 2009) digital city depiction and does not match the scope of this study.
In short, digital city is a developing city model of urban technology related to the creation of cultural, social, economic, and educational data related to citizens. Any city with communication, telecommunication and virtual city features can come across digitally.

\section{INTELLIGENT CITY}

Another term that emerged with the developing city technology is the concept of intelligent city. This concept started to form in the 80s-90s like the other two concepts and many local and governmental authorities, business and other third participants have worked on this concept (Lipman et al., 1986; Kingston et al., 2005).

Intelligent city is the solution of all kinds of services over a certain network system. By transferring the physical features of the existing urban space to an urban online network, it shapes the intelligent technology according to the existing urban features (Komninos, 2011).

In addition, intelligent cities have intelligent communities and this structural structure increases the cognition and innovation level of the city (Komminos, 2006).

This network system operates in line with the information obtained by teleport providers in the city (Lipman et al., 1986). Intelligent city not only tries increase the efficiency of the urban system, but to work in a regular and grounded manner (Yovanos, Hazapis, 2009). The aim of intelligent cities are (Kingston et al. 2005):

1. Supporting the daily needs and activities of residents, businesses, and visitors of the city

2. Receiving and directing information from the city government, transportation system, security system and other service providers

3. Thanks to the developing drawing technologies, to realize a better urban planning by predicting the effects of structural changes on urban and rural life

Manchester (UK), Taipei (Taiwan), Spokane (USA), Songdo (Korea), and Cyberjaya and Putrajaya (Malaysia) and Neapolis (Cyprus) are some examples of the intelligent cities. There are approximately 175 intelligent cities in the world (Estevez et al., 2016; Intelligent Community, nd.).

Intelligent city has more overlapping definitions in the literature, like digital city. Some of these definitions are given in Table 4 .

\begin{tabular}{|l|c|c|}
\hline Definition & Who & Date \\
\hline $\begin{array}{l}\text { the transformation of urban life } \\
\text { participants and elements into } \\
\text { spatial intelligence architecture } \\
\text { within the framework of an } \\
\text { institutional cooperation. }\end{array}$ & Komninos & 2011 \\
$\begin{array}{l}\text { the transformation of the hardware } \\
\text { of urban space and urban } \\
\text { technology into a kind of artificial } \\
\text { urban nervous system in } \\
\text { collaboration with the software. }\end{array}$ & Mitchell & 2007 \\
$\begin{array}{l}\text { to improve the services provided } \\
\text { to citizens and businesses through } \\
\text { electronic city management. }\end{array}$ & Kingston et & al. \\
\hline
\end{tabular}




\begin{tabular}{|l|c|c|}
\hline Definition & Who & Date \\
\hline $\begin{array}{l}\text { It is the collection and connection } \\
\text { of urban structures, transportation } \\
\text { plans with various interactive }\end{array}$ & Weinstock, & \\
$\begin{array}{l}\text { information systems and } \\
\text { development systems for } \\
\text { municipal and private services and } \\
\text { governance. }\end{array}$ & Gharleghi & \\
$\begin{array}{l}\text { A system includes that innovation, } \\
\text { education, knowledge creation and } \\
\text { problem solutions }\end{array}$ & $\begin{array}{c}\text { Estevez et } \\
\text { al. }\end{array}$ & 2016 \\
\hline
\end{tabular}

Table 4. Definitions in literature about intelligent cities

Briefly, intelligent city is the technological computing and management network required for the smooth urbanization of physical urban components, residents, and other city participants.

\section{SIMILARITIES, DIFFERENCES AND OBSTACLES}

When these concepts are viewed from a general framework, it is observed that the similarities between the concepts are more than the differences.

The great interest in the concept of smart city recently has not been shown much in the other two concepts in the time they appeared. While conducting this study, more scientific articles about smart city were found in the literature research and the resources were reached more easily.

However, the European Union, which adopted the first climate law of Europe in March 2020 and made sustainability, smartness and economic growth its mission (European Commission, 2020; European Commission, 2010), continued its studies on these 3 concepts and created projects and calls related to these concepts (Engelbert et al., 2019; Kingston et al. 2005; van Bastelaer, 1998.

Also, considering the basic similarities of the concepts, it is necessary to examine the themes they want to turn to and the criteria they have created within themselves.

The determined criteria of smart city are (Sharifi, 2019):
1. Smart economy
2. Smart people
3. Smart data
4. Smart mobility
5. Smart living
6. Smart governance
7. Smart environment

In general, even though the researches mention 6 criteria (Sikota-Fernandez, Stawasz, 2016) Sharafi (2019) emphasized that there should be smart data. Table 5 shows the areas of interest for these concepts.

Except for good information, urban communication and community network, there is no clearly defined criterion for a city to become a digital city. But the characteristics that must be found in a digital city have been determined (Schuler, 2002; van Bastelaer; 1998):

\author{
1. Commercial \\ 2. Governmental \\ 3. Educational \\ 4. Representational \\ 5. Informative
}

Digital City has a more social and economic dimension. Social connection and virtual network are the key phenomena of the concept. By the existence of these two key phenomena, the growth of technological development and the development of the economy occur in the virtual adoption of the city.

Moreover, when people focus on the concept of intelligent city, these features are important (Lipman et al., 1986):
1. Accessibility
2. Flexibility
3. Reliability
4. Economy
5. Dependability
6. Knowledge,
7. Planning,
8. Quality of life
9. Growth
10. Site use
11. Land availability

The features like knowledge, quality of life and economy are the features they are interested in in the other two concepts. Table 5 gives the areas that these 3 concepts examine and emphasize.

\begin{tabular}{|c|c|c|}
\hline Areas & Smart City $\begin{array}{l}\text { Digital } \\
\text { City }\end{array}$ & $\begin{array}{l}\text { Intelligent } \\
\text { City }\end{array}$ \\
\hline Education and Learning & & \\
\hline $\begin{array}{l}\text { Information and } \\
\text { Network }\end{array}$ & & \\
\hline $\begin{array}{l}\text { Sustainable } \\
\text { Environment }\end{array}$ & & \\
\hline Mobility & & \\
\hline Quality of Life & & \\
\hline Business and Economy & & \\
\hline Government & & \\
\hline Technology and Data & & \\
\hline Urban Land & & \\
\hline Urban Planning & & \\
\hline $\begin{array}{l}\text { Protection of The } \\
\text { Existing }\end{array}$ & & \\
\hline $\begin{array}{l}\text { Social and Cultural } \\
\text { Features }\end{array}$ & & \\
\hline Urban Services & & \\
\hline Citizen Knowledge & & \\
\hline
\end{tabular}

Furthermore, it is observed that different structural clusters (Komminos, 2006) have some way of communicating with each other in these concepts. In this case, these 3 concepts cannot be considered as concepts that only architectural or computer engineering should work. All disciplines that are interested in all the cluster formations that make the city urban should work 
together under the roof of smart, digital, or intelligent cities. Interdisciplinary studies will improve urban technology.

At the same time, it is a desired and expected situation for citizens to use these technologies and use existing conceptual systems with hardware and software systems in some way in all concepts (Lenormand, 2014).

However, in many planning and the first conceptual structuring developed, city residents are somehow neglected, in fact, social connections and human-related regulation, which are the basis of digital city and smart city, are the latest criterion (Engelbert et al., 2019; Schuler; 2002).

In addition, when searches related to these concepts are made in search engines, the results and web pages that are pointed out differ. In other words, if local government does not inform, it can be quite difficult for city citizens to experience developments related to urban technologies.

Generally, citizens can be isolated, because they don't informed very well, local governments has a lot to do about this. It is important to remember that citizens work as human sensors of the system (Mostashari et al., 2011).

In addition, although transportation and mobility are very important in these three concepts, it is wrong to place this event developed on the basis of urban technology at the centre of the concepts. It is important to consider all criteria, elements and indicators of these holistic systems while creating concepts.

Moreover, although areas such as quality of life, smart living, smart people and community network emphasize the social aspects of these concepts, wellbeing and healthcare are not included in these areas. Although some publications which are related to these concepts have been analysed as subtitles, it has shown that the health system of the pandemic period should also work with smart urban technologies. Technological innovations can take the information and direction of the pandemic in the city to a better level.

\section{CONCLUSION AND FUTURE STUDIES}

It is observed that they have intersecting points in each of the 3 terms. Urban technology, computing, IoT and ICT are the key components in the formation of these concepts. At the same time, considering the definitions in 3 concepts, human, service management, economy and local management are arranged in a way.

Although some sources say that the concept of 3 occurred in the 90s, digital city and intelligent city are older concepts compared to smart city, with the growth of smart city's sustainability concept is emerging as a richer state of intelligent and digital city.

Because now, with the guidance and demands of today's communication society and globalization, every local government is developed or developed in the way of digitalization. Even though urban planning is mentioned in concept of intelligent city, it is seen that sustainability is not only addressed in terms of technological and systematic aspects, but environmental sustainability is not mentioned.

In addition to all this information, it can be said that the concept of smart city covers two other terms. However, it should be underlined that the smart city is not only a vision directed by
BIG DATA, it can also use passive systems in place and on time (economically, socially and environmentally) and also, while equipped with BIG DATA and urban technologies, the city's existing resource values are preserved.

In terms of the meanings of the terms smart, intelligent and digital, it is seen that the word smart is in the context of logic, in an appropriate place, at the appropriate time, at the appropriate time and in an action such as doing the appropriate one.

The missing work is to explain these concepts to better people and to find their limits. It was observed in the Corona era that mankind is not within digital limitation. The real limit is to leave an important factor like "citizen" to the end while studying the concepts.

Because people who are unable to fully discriminate between concepts or who are non-disciplinary, especially residents of the city should be well informed about the concepts. For example, when searching for "intelligent cities in the world" in the Google Search Engine, the first answer given is the "The Top Ten Smartest Cities in the World" list published on Forbes's website. On the other hand, when Bings replied in an article entitled "The Ten Smartest and Intelligent Cities in the World" by SUNTRUST BLOG's Iniobong nickname in 2019, Yandex showed the article "The Most Intelligent Cities in the World" written by Parry in 2015 on the Lostwaldo website. These distinct responses can mislead people who do not know the concepts fully or who are unable to search for an academic literature.

While even the simplest, fastest and easiest search method brought by technology can not reveal these concepts simply, removing the confusion and disregard of citizens' feelings towards these concepts should be the primary priority. Because one of the structural elements that make the city a city is society.

Also, in this pandemic period, the use of technology of the global community has increased involuntarily at this time. The values that can be achieved through information, increasing the quality of human life and urban and global technology in this limited environment have been achieved with the help of the identities that cities have gained globally thanks to technological development and digitalization. In addition, health checks and information systems caused us to question the digital infrastructures and smart equipment of cities again (New China TV, 2020). Perhaps it's time to re-examine which is the smartest city or country in the world.

\section{REFERENCES}

Alkan, T. (2015). Ak1llı kentler ya da 21. Yüzyıl şehirleri. Bilişim Dergisi, S, 182, 70-77.

Ateş, M., Önder, D. E., 2019. 'Akıllı Şehir'Kavramı ve Dönüşen Anlamı Bağlamında Eleștiriler. Megaron, 14(1).

BBC Turkish., 2020. Koronavirüs nedir: Covid-19 hastalığının semptomları neler, hangi önlemler alınmalı? https://www.bbc.com/turkce/haberler-dunya-51177538, accessed date 7 April 2020.

Berrone, P., Ricart, J. E., Carrasco, C., \& Duch, A., 2019. IESE Cities in Motion Index 2018, IESE. ST-509-E. Available online: 
https://media. iese. edu/research/pdfs/ST-0509-E. pdf, accessed date 25 May 2019.

Braun, B., 2005. Environmental issues: writing a more-thanhuman urban geography. Progress in human geography, 29 (5), 635-650.

Castells, M., 1999. Grassrooting the space of flows. Urban Geography, 20(4), 294-302.

Castells, M., 2004. Informationalism, networks, and the network society: a theoretical blueprint. The network society: A cross-cultural perspective, 3-45.

Caragliu, A., Del Bo, C., Nijkamp, P., 2011. Smart cities in Europe. Journal of urban technology, 18(2), 65-82.

Çelik, S., \& Güleç, G., 2014. Kentleşme ve eğitim sürecinde okul binaları. Eğitim Bilimleri Araştırmaları Dergisi, 4-18.

Dameri, R. P., 2013. Searching for smart city definition: a comprehensive proposal. International Journal of computers \& technology, 11(5), 2544-2551.

DG-Energy, 2019. Smart Cities - Smart Living. https://ec.europa.eu/digital-single-market/en/smart-cities, accessed date 6 June 2020.

DG-Energy, n.d.. Energy and smart cities | Energy - European Commission., https://ec.europa.eu/energy/topics/technologyand-innovation/energy-and-smart-cities_en, accessed date 6 June 2020

Enelx, n.d.. What does Digital City mean?, https://www.enelx.com/en/questions-and-answers/ecity/whatdoes-digital-city-mean, accessed date 14 July 2020

Engelbert, J., van Zoonen, L., Hirzalla, F., 2019. Excluding citizens from the European smart city: The discourse practices of pursuing and granting smartness. Technological Forecasting and Social Change, 142, 347-353.

Estevez, E., Lopes, N., Janowski, T., 2016. Smart sustainable cities: Reconnaissance study.

European Commission., 2020. REGULATION OF THE EUROPEAN PARLIAMENT AND OF THE COUNCIL establishing the framework for achieving climate neutrality and amending Regulation (EU) 2018/1999 (European Climate Law)

European Commission (EC), 2010. EUROPE 2020: A strategy for smart, sustainable and inclusive growth. Working paper \{COM (2010) 2020\}.

Kingston, R., Babicki, D., Ravetz, J., 2005. Urban regeneration in the intelligent city. In Proceedings of the 9th International Conference on Computers in Urban Planning and Urban Management, 1-17.

Intelligent Community n.d. List of All Intelligent Communities. https://www.intelligentcommunity.org/intelligent_communities _list , accessed date 20 June 2020

Ishida, T., Isbister, K. (Eds.), 2000. Digital cities: technologies, experiences, and future perspectives. Springer Science \& Business Media.
Komninos, N., 2011. Intelligent cities: Variable geometries of spatial intelligence. Intelligent Buildings International, 3(3), 172-188.

Komninos, N. 2006. The architecture of intelligent cities. Intelligent Environments, 6, 53-61.

Kotzeva, M. M., Brandmüller, T., (Eds.), 2016. Urban Europe: statistics on cities, towns and suburbs. Publications office of the European Union.

Lipman, A. D., Sugarman, A. D., Cushman, R. F. (Eds.), 1986. Teleports and the intelligent city. Homewood, IL: Dow JonesIrwin.

Louail, T., Lenormand, M., Ros, O. G. C., Picornell, M., Herranz, R., Frias-Martinez, E., ..., Barthelemy, M., 2014. From mobile phone data to the spatial structure of cities. Scientific reports, 4, 5276 .

Mitchell, W. J., 2007. Intelligent cities. UOC papers, 5, 3-8.

Mostashari, A., Arnold, F., Mansouri, M., Finger, M., 2011. Cognitive cities and intelligent urban governance. Network Industries Quarterly, 13(3), 4-7.

New China TV, 2020. China turns to AI, robots in coronavirus control, https://www.youtube.com/watch?v=7YVzWgyMbl8, accessed date15 February 2020

Nunes, F., 2005. Aveiro, Portugal: Making a Digital City. Journal of Urban Technology 12(1):49-70.

Paull, L., 2020. Art, concerts and museums during a pandemic: What is 'local'?, https://www.jweekly.com/2020/03/27/artconcerts-and-museums-during-a-pandemic-what-is-local/, accessed date 22 June 2020

Sassen, S., 1991. The global city. New York.

Schuler, D., 2001. Digital cities and digital citizens. In Kyoto Workshop on Digital Cities, 71-85. Springer, Berlin, Heidelberg.

Sharifi, A., 2019. A critical review of selected smart city assessment tools and indicator sets. Journal of cleaner production, 233, 1269-1283.

Sikora-Fernandez, D., \& Stawasz, D. 2016. The concept of smart city in the theory and practice of urban development management. Romanian Journal of Regional Science, 10(1), 8199.

Van Bastelaer, B., 1998. Digital cities and transferability of results. In 4th EDC Conference on digital cities, Salzburg 6170 .

Van den Besselaar, P., Melis, I., \& Beckers, D. (1999, September). Digital cities: organization, content, and use. In Kyoto Workshop on Digital Cities (pp. 18-32). Springer, Berlin, Heidelberg.

Velibeyoğlu, K., 2016. Akıllı kentler: vaatler ve ötesi. Yenilikçi Sürdürülebilir Gelişme Stratejileri Bağlamında Türkiye Ekonomisinin Geleceğine Yönelik Çözüm Arayışları. 
Weinstock, M., Gharleghi, M., 2013. Intelligent cities and the taxonomy of cognitive scales. Architectural Design, 83(4), 5665 .

Шнепс-Шнеппе, М. А., 2016. How to build a smart city. Part 1. The project" Smart Cities and Communities" in the EU Horizon 2020. International Journal of Open Information Technologies, 4(1), 12-20.

Yovanof, G. S., Hazapis, G. N., 2009. An architectural framework and enabling wireless technologies for digital cities $\&$ intelligent urban environments. Wireless personal communications, 49(3), 445-463. 